This is the author's final, peer-reviewed manuscript as accepted for publication. The publisher-formatted version may be available through the publisher's web site or your institution's library.

\title{
Place attachment among retirees in Greensburg, Kansas
}

Jeffrey S. Smith and Matthew R. Cartlidge

\section{How to cite this manuscript}

If you make reference to this version of the manuscript, use the following information:

Smith, J. S., \& Cartlidge, M. R. (2011). Place attachment among retirees in Greensburg, Kansas. Retrieved from http://krex.ksu.edu

\section{Published Version Information}

Citation: Smith, J. S., \& Cartlidge, M. R. (2011). Place attachment among retirees in Greensburg, Kansas. Geographical Review, 101(4), 536-555.

Copyright: Copyright $\odot 2011$ by the American Geographical Society of New York

Digital Object Identifier (DOI): doi:10.1111/j.1931-0846.2011.00116.x

Publisher's Link: http://onlinelibrary.wiley.com/doi/10.1111/j.1931-

0846.2011.00116.x/abstract

This item was retrieved from the K-State Research Exchange (K-REx), the institutional repository of Kansas State University. K-REx is available at http://krex.ksu.edu 


\title{
Place Attachment Among Retirees in Greensburg, Kansas Jeffrey S. Smith and Matthew R. Cartlidge
}

\section{For a complete pdf version of this article visit: www.k-state.edu/geography/JSSmith/}

\begin{abstract}
On May 4, 2007, an EF-5 tornado passed through Greensburg leveling 95 percent of the town. Because city leaders encouraged everyone to use "green" building techniques as they rebuilt their homes and businesses, not only has the return to normalcy been exceedingly slow, but some of the town's older residents feel that officials overlooked their needs. These minor episodes of discord enabled us to learn what features are most important to people in their retirement-age. They include: identifiable landmarks, a space to socialize, and agespecific businesses. We assert that the lessons learned in Greensburg are applicable to other communities with a sizeable older-aged population. As baby boomers rapidly enter retirement they will seek places to live that are elderly-friendly and enable them to effectively bond with place. As previous research attests, people who have a strong attachment to place commonly lead a good quality-of-life.

Keywords: attachment to place, baby boomers, Greensburg Kansas, retirees.
\end{abstract}

On the night of May 4, 2007, residents in Greensburg, Kansas took to their tornado shelters like they had done many times before. When the emergency sirens stopped blaring and they emerged from their earthen bunkers the town and life they knew before the storm was gone. In less than five minutes, the tornado’s $200 \mathrm{mph}$ winds not only destroyed 95 percent of the town's homes and businesses, but it irretrievably stole the things that gave order and meaning to peoples’ lives. 
Within the United States, between 2000 and 2009, natural disasters killed 4,267 people and displaced more than 20 million individuals (EM-DAT 2011). In the aftermath of a natural disaster, affected residents must decide whether they will stay and rebuild or resettle in a new location. Financial costs, ongoing risk, and interpersonal relations are among the most important factors, but the decision boils down to how emotionally connected people feel toward the place. Previous research tells us that, people who possess a strong emotional bond to a place are more likely to return and rebuild in the wake of a natural disaster (Chamlee-Wright and Storr 2009).

For people in their retirement years ${ }^{1}$, the decision to build anew after a disaster is even more difficult because they must weigh the long-term financial costs and benefits, as well as speculate how long their diminishing physical abilities and cognitive skills (Lawton 1980) will enable them to remain independent. A natural disaster may act as a catalyst in the lives of older folks and force a decision. Some retirees may decide that moving to an age restricted retirement community with various levels of assistance is desirable. For others such a move calls into question their self identity and independence as well as their ability to care for themselves. However, if they choose to rebuild, they are faced with the challenge of adjusting to a rebuilt community that may not resemble the one they lost to the devastating event. Ultimately, the decision comes down to quality of life and how attached the older folks are to the community in which they live. The growing body of scholarship on attachment to place provides considerable insight into the significance of place attachment for populations as a whole. Curiously, the literature is nearly silent when it comes to understanding what enables older residents to develop a strong bond to the community in 
which they live. Moreover, if a natural disaster destroys the place where older folks reside, what aspects within the community do they miss the most? The purpose of this article is to explicate what elements of the cultural landscape enhance retirees emotional connection to place. To help answer these questions we examined the town of Greensburg, Kansas as it rebuilds following a devastating tornado in 2007.

\section{Rebirth of Greensburg}

Greensburg, founded in 1884, became a water refueling station along a spur of the Santa Fe Railroad and slowly grew to become a principal political and commercial center for residents in the region (Hayse et al. 1979) (Figure 1). In 1960 the town's population peaked at 1,988 people (U.S. Census 1961), but like so many other rural, isolated communities in the American Great Plains, Greensburg saw its population steadily dwindle over the subsequent five decades (Table 1). Because few off-farm employment opportunities exist, the town has experienced the ill effects of youth drain migration (Adamchak et al. 1999). A majority of the town's younger population has out-migrated after completing high school thereby leaving a very skewed population distribution. In 2000, 26.4 percent of Greensburg's 1,574 stalwart residents were 65 years of age or older² (U.S. Census 2001).

When the EF-5 tornado passed through Greensburg leveling the town and killing fourteen people, the strong winds destroyed the central business district and left all but a handful of houses in ruin. In the aftermath, the consequences forced long-time residents and

civic leaders to decide the fate of their town. One group understood that any effort to rebuild the decaying town was simply forestalling the inevitable. The larger, prevailing group, 
however, felt Greensburg was still a viable community and pushed to resurrect the town using "green" (environmentally sustainable) building techniques (Figure 2). Moreover, the town has embraced the role as laboratory for innovative thinking and host to a wide variety of scholarly research.

Greensburg is an ideal case study site for three main reasons. First, with 95 percent of the town wiped clean, Greensburg provides a rare opportunity for cultural geographers to observe and examine what features in the cultural landscape are significant to retirees within the community. Second, because the town has decided to build "green," the pace of recovery and return to normalcy has been exceedingly slow. Up-front building costs have been as much as 20 percent higher than traditional building techniques because most construction materials have to be shipped in from considerable distances. As a result, between 2007 and 2010 residents rebuilt less than half the town. On the third anniversary of the catastrophic event, homes and businesses were still under construction and contractors had just completed government buildings, banks, and churches. The downtown still does not resemble its former state. Rarely is one given the opportunity to watch the cultural landscape rematerialize at such a plotted pace. Finally, as community leaders embraced and focused on "rebuilding green,” they sometimes overlooked the needs of the town's elderly constituents. These mistakes or oversights led to minor episodes of discord within the community enabling us to learn what features and elements were most important to the retirement-age population.

After securing IRB approval, we collected data using a variety of methods from sources including archival records, pre- and post-tornado photography, an analysis of the cultural landscape, and participant observation. The most fruitful source of information, 
however, originated from the forty-five semi-structured interviews conducted with Greensburg's past and present residents. We contacted a cross-section of community members during the tornado's second anniversary. Through snowballing from those initial contacts we covered a wider swath of the town's demographic profile. Moreover, elected officials, community leaders, and business owners provided additional insight into the town's evolving character. From a select, manageable group of key informants, we garnered additional information through a cognitive mapping exercise. A cognitive map, also referred to as a mental map, is a visual representation of the spatial organization and meaning an individual attaches to a place. As Kevin Lynch (1960) reports, mental maps commonly include five elements: paths/routes, nodes/juncture points, landmarks, districts/zones, and edges/boundaries. Researchers use mental maps to identify significant locations and place perceptions within a person's activity space. We employed this research technique by asking ten residents from a wide cross section of the community to draw Greensburg both before and after the destructive event. We analyzed their mental maps looking for spatial patterns, key landmarks, and consistencies in content that might reveal what cultural landscape features contribute to an emotional connection to place. We logged all data collected in field journals and retained them for future reference.

\section{Attachment to Place}

Edward Relph (1976) indicates that one of the fundamental aspects of human nature is our tendency to develop strong emotional ties to a place. We find ourselves attached to places because they help fulfill basic human needs (Tuan 1974; Relph 1976). The place most 
people develop their strongest affinity for is called home because it holds the deepest personal, emotional ties. Home (whether literally or figuratively) can be a place of refuge or it can be filled with particularly moving experiences (Relph 1976).

The deep-seated emotional connection people have with a place has been the subject of scholarly research for half a century. The literature refers to the concept numerous ways including: topophilia (Tuan 1974), rootedness (Relph 1976; Tuan 1980), insideness (Relph 1976; Rowles 1990), place identity (Proshansky et al. 1983), homeland (Nostrand and Estaville 2001) and most commonly place attachment (Altman and Low 1992). According to Maria Giuliani (2003), psychologist Marc Fried completed the first study on the bond people make with a place when, in 1963, he examined Boston's West End. He found that residents were so strongly attached to their neighborhood that when the city began its program of urban renewal, locals felt a deep sense of loss and sorrow akin to losing a loved one (Fried 1963).

In the mid-1970s the work of cultural geographers (particularly Edward Relph and Yi-Fu Tuan) started gaining considerable notoriety for their application of the phenomenology perspective, which advocates understanding human experience and the perceptions people have for places. In Place and Placelessness, Relph (1976) asserts that one's identity is largely derived from the interaction and bonding a person has with a place. In 1974, Tuan published Topophilia (love of place) which helps readers understand the emotional connection people make with places. Whereas Topophilia focused largely on a place’s aesthetic qualities, two years later Geopiety (1976) helped audiences begin to grasp people’s reverence for home and their pious devotion to a land or country. In Space and 
Place (1977), Tuan added even more substance by exploring the fond memories people have for particular places and how reassuring those places become. As Tuan points out, "the more ties there are [to a place], the stronger is the emotional bond" (Tuan 1977, 158).

Beginning in the 1980s, scholars from a wide variety of other disciplines started exploring the emotional bonds people make with a place. A review of this vast and rapidly expanding body of literature shows that individuals form an attachment to place for a wide variety of overlapping reasons (Scannell and Gifford 2010). As Low and Altman (1992) explain, place attachment involves the complex interplay of emotions, beliefs, and actions centered on a place.

At one level, a place can become an anchor in our lives by offering a certain level of safety, security, and control in an otherwise chaotic world. At a deeper, more emotional level however, places become significant in our lives because they may remind us of our interpersonal relations with others. It is in these places that our emotional connections with family, friends, and even ancestors come out. Furthermore, as Lynne Manzo (2005) discovered, people tend to bond with those places where significant events or milestones took place (e.g. the place of a wedding proposal).

In other cases, people develop bonds with a place because the location helps reify their identity as individuals or as members of a culture group (Proshansky et al. 1983; Low and Altman 1992; Scannell and Gifford 2010). For example, as residents of a particular community (e.g. church, social club, benevolent organization) participate in public life, they form relationships with others that commonly lead to a bonding with the place where those events occur (Hayden 1997). Moreover, the meaning that individuals or groups of people 
attach to a particular place can help reinforce societal norms and cultural traditions (Smith et al. 2001; Smith and White 2004).

Central to any study on place attachment is the focus on the qualities and characteristics of a particular place. Geographers have made some significant contributions in this area of research. Ben Marsh (1987) provides a classic example when he explains that, despite endemic poverty and economic collapse, residents in the anthracite mining towns of northeastern Pennsylvania refused to leave their home communities because of their unconditional bonds with the place and sense of rootedness. Marsh's work teaches us that people's attachment to place is a result of the complex interplay between the historical means (economic foundation) and the ongoing meaning (cultural, emotional significance) of a place. More recently, place attachment research has become ever more sophisticated as scholars seek to disentangle the characteristics of a place and the subtleties of people's bonding with a location. For instance, Steven Schnell (2003) uncovers connections between heritage tourism, ethnic identity, and place attachment among residents in Lindsborg, Kansas. He found that the repackaging of the town's ethnic identity not only helped preserve the local Swedish heritage, but also fostered deep seated feelings of attachment among members of the community. More recently, Brown and Raymond (2007) used Australia’s Great Otway National Park to examine the complex relationship between the physical landscape and people’s attachment to place. Their work demonstrates that aesthetic, economic, recreational, spiritual, and therapeutic activities are most important in explaining why people bond with a place. 
Realizing the importance that place attachment plays in the long-term economic vitality of a community, in 2008 Gallup Inc., in conjunction with the Knight Foundation, embarked upon a multi-year study of 26 U.S. cities to identify what elements help residents develop an emotional bond to their community (Gallup and Knight 2010). Surprisingly, after interviewing 43,000 people, the study found that instead of economic, employment, and safety related factors, people are more likely to develop strong connections to communities that are attractive and aesthetically pleasing, offer ample opportunities for socializing, and are “open” and receptive to people with diverse backgrounds and interests.

As research on place attachment continues to expand and evolve, scholars have begun probing into other variables that affect people’s strong connection with place. One theme gaining considerable traction involves the study of place attachment among different age groups. Some studies have looked at children (Derr 2002) or adolescents (Pretty, Chipuer, and Bramston 2003; Chow and Healey 2008; Morgan 2010). More of the work however, has explored place attachment among older-aged adults (Lawton 1980; Rowles 1990; Rubinstein and Parmelee 1992; McHugh and Mings 1996; Alley et al. 2007; Gilleard, Hyde, and Higgs 2007; Wiles et al. 2009). These and other studies point to how different age groups bond with place. Robert Hay (1998), for example, found that children develop longer lasting ties to place than adults, yet the emotional connection people have with a place tends to increase with age. For the elderly, "places with deep emotional connection foster a sense of self, strengthen self image, and allow people to retain a positive self concept as their life and circumstances change” (Low and Altman 1992, 10). 
One of the newest lines of scholarship combines the purview of environmental hazards research with place attachment. For example, research spearheaded by Shirley Laska probes how people react to the protracted loss of coastal lowlands (Burley et al. 2007). The study finds that when individuals feel that a fragile environment or unique way of life is being threatened, their level of attachment to those places tends to increase. The aftermath of Hurricanes Katrina and Rita has provided numerous other scholars with a window to understanding not only the process of recovery, but the factors that impact residents' deepseated connection to place. For instance, economists Emily Chamlee-Wright and Virgil Storr (2009) discovered that the key to recovery and a return of people’s place attachment is the reintroduction of basic infrastructure (e.g. electricity and water), supportive retail (e.g grocery store), and community services (e.g. schools and hospitals) around which other rebuilding efforts can occur. Studies such as these provide insight into place attachment for the population as a whole. However, we know little about how older residents respond when a natural disaster destroys their community. What elements are most important to them?

We assert there are lessons to be learned from Greensburg, Kansas, not because it is the only location with a large proportion of retirees or a place where people's attachment to place has been examined after the cultural landscape has been drastically altered, ${ }^{3}$ but rather because the town has decided to rebuild "green” it has progressed very slowly allowing observers to see what is important in meeting the needs of older residents. By analyzing how events have unfolded as Greensburg has rebuilt after the 2007 tornado, we seek to shed more light on what elements help retirees remain rooted in place and therefore maintain a high quality of life. 


\section{Re-Creating a Place for Retirees in Greensburg}

In the five minutes that the EF-5 tornado tore through Greensburg, it not only flattened the town but it dramatically changed the lives of its residents. In early 2011 nearly four years had passed since that catastrophic event, yet the road to recovery continued to be slow and filled with unexpected challenges. Oversights and omissions by community leaders have added stress to the lives of the town's retirees who comprise 26.4 percent of the population. These episodes of discord or unfortunate happenstance have afforded us the opportunity to identify what elements in the cultural landscape are most important to the retirement-aged population and help them maintain a strong attachment to the community. Our research reveals that these features include: recognizable landmarks, places to socialize, and age-specific services.

\section{A Landscape Filled With Familiar Landmarks}

According to environmental psychologist M. Powell Lawton (1980) every individual is born with a certain “level of competency” that is rooted in one’s physical abilities (e.g. sensory skills, strength, coordination) and cognitive skills (e.g. capacity to think, adapt, and solve problems). For healthy, able individuals their level of competency allows them to handle the environmental stresses of daily life. As we age, however, our level of competency tends to diminish and we can become overtaxed by the environment in which we live. In such situations we seek coping mechanisms to help us function within that over-stressed environment. Geographer Graham Rowles (1990) provides one example of a coping 
mechanism when he asserts that older individuals who have lived in the same community for an extended period of time develop a heightened attachment to place he calls physical insideness. This elevated level of familiarity and intimate knowledge of a place that comes with years of living there enables older people to traverse their community with confidence and security. In Phoenix, Arizona, for example, retirement communities commonly display landmarks (e.g. distinctive signs, major icons, or unique landscaping) that help residents identify their neighborhood (Blake and Arreola 1996).

Prior to the 2007 tornado, Greensburg was a typical small town on the American Great Plains. Modest homes shaded by stately deciduous trees lined its grid-pattern streets. Disbursed throughout the community were various buildings (e.g. county courthouse, high school, and public library) that provided local residents with a rich source of pride. Although the businesses in the unassuming downtown could not compete with the modern shopping malls in far away cities, they provided most of the local retail needs. On the town's flanks stood a water tower and grain elevator. What made Greensburg distinctive is that it hosts the world's largest hand dug well. ${ }^{4}$ To local residents, not only is the well a source of tourism revenue, but it has long served as one of the town's most important landmarks.

In conversations with local residents, landmarks such as the “Big Well” helped people (especially the older folks) navigate their way through town. For example, 63 yearold Janice Keller (2009) says that prior to the storm she relied upon prominent buildings and eye-catching houses to find her way through the community. For other long-time residents, it was the businesses in town that served as key landmarks. On the east side stood the John Deere Farm Equipment dealership and the west side was home to the regional hospital. For 
people like 59 year-old Mike Case (2009) these were two of the biggest anchors in the community; they served as important points of reference.

In the immediate aftermath of the devastating tornado, nearly all residents of Greensburg, particularly retirees, found it exceedingly difficult to navigate through town because the landmarks they once used as navigation tools had all been destroyed. Many of the older people we talked with expressed considerable frustration because nothing looked familiar. Gone were the distinctive houses and buildings. It was as if they had been dropped into a foreign land. ${ }^{5}$ Largely overlooked before the event, residents quickly began using the unscathed, unadorned, three-story, concrete grain elevator on the northern edge of town as their main point of reference (Figure 3). It became the town's most identifiable landmark. As time passed, other landmarks slowly began to present themselves.

Intuitively, one might expect street signs to serve as landmarks and aid in navigation. For Greensburg's retirees the newly replaced street signs were of little use because they are typically too small and exceedingly difficult to read while driving. Coincidently, students at a local school made street-level, hand-painted signs large enough to read from a distance (Figure 4). According to our sources, these informal signs not only became a source of pride and emotional support for the town's residents, but they served as useful landmarks within the community, especially for the retirees. Eventually, community leaders responded to the disorienting landscape by offering every household a yard sign with their family name boldly printed on it (Figure 5). This successfully established new landmarks to aid people as they negotiated through town. 
One of the most significant landmarks in Greensburg came eighteen months after the tornado when the government finally completed the large subsidized housing complex. The modern, single-story homes fill all four sides of a city block and offer low-income families affordable housing. By the summer of 2009, the completion of other key buildings (including a bank, John Deere dealership, and government building) added even more landmarks to the cultural landscape. Furthermore, as rebuilt homes became occupied, the residents embellished them with personal touches. Ironically, despite their reluctance to embrace the environmentally friendly building techniques, the retired-aged population in Greensburg has found some of the "green” houses particularly helpful as landmarks because they stand out like sore thumbs (Figure 6). Slowly Greensburg is adding new landmarks, but the process is proceeding slowly and has frustrated many of the town's older residents.

\section{A Place to Gather and Reinforce Community Ties}

In northern New Mexico and southern Colorado the long-time Spanish-speaking residents use the word resolana to refer to any place where people of all ages sit in the warmth of the sun during winter or under a shady tree in summer and wile away their spare time. Nearly every Hispanic village in the upper Rio Grande region has a community gathering place. As part of their research on place attachment, Scannell and Gifford (2010) report that a vital ingredient needed for healthy social group interaction is a space where people can meet others who share common connections (e.g. income, gender, age, religion). Psychologists Setha Low and Irwin Altman (1992) conclude that it is the spaces filled with 
personal connections and social interaction that are key to understanding people's attachment to a place. Such places provide people with a caring supportive community (Rowles 1990).

Prior to the upheavel wrought by the EF-5 tornado, the most common place for Greensburg's retirees to socialize was the Kansan Restaurant. Generously, the owner set aside a table next to the dining area where locals could gather with a cup of coffee and talk. According to our contacts, people in attendance resolved few major issues. Rather, it was an opportunity for residents with plenty of time on their hands to interact and reinforce their ties to the community. In the weeks following the tornado those same people had little need for a place to meet; their focus was on salvaging their belongings. As time passed, however, they started looking for a dedicated space to socialize. For many of the town's older residents the post office was the initial place that served this purpose. As 95 year-old Winnie Fankhouser explains, going to the post office became the highlight of her day. She saw many of her friends and neighbors there and her life felt somewhat normal again (Fankhouser 2009). It was not until personnel at the Kiowa County Mental Health Department finally started offering counseling services that older residents realized how important it was to have a place to socialize. Mental health officials responded by providing free coffee and a large table in the corner of their storage shed for retirees to congregate. It became evident to health officials that the most significant advances in psychological healing took place informally when the Health Department reestablished a dedicated social space (Truman 2009).

Churches provide an obvious location for socialization and community support. Prior to the tornado, seven houses of worship served Greensburg's religious needs. The strong winds left none of them standing. As community members focused on rebuilding their lives 
after the storm, they overlooked the importance of the church buildings. For seventeen months all seven congregations gathered and worshiped in informal structures (e.g. private residences and oversized tents) (Dawson 2009). Some of the churches even held services outside the town limits. For 88 year-old Ruth West, driving by the vacant lot where her old church once stood was an incredible disappointment and source of consternation (West 2009). As Greensburg's rebuilding process continued, many of the older residents became increasingly frustrated with all of the focus on building "green" and a lack of permanent houses of worship. To them religion and the sense of community that accompanied going to church always played a central role in their lives. The longer Greensburg went without permanent church buildings the more disconnected the older residents felt from the community. By the third anniversary of the catastrophic event, parishioners dedicated the last of the seven new churches. As numerous older residents told us, once the churches returned the community felt like home again.

\section{Age-Specific Businesses and Services}

Before May 4, 2007, Greensburg’s commercial district was small but it met most residents’ needs, including those people in their retirement years. From our informal interviews and content analysis of people’s mental maps, we learned that Duckwalls general merchandise, Hunter Drug, Dillons grocery, Fleener’s Furniture, the Kiowa County Library, Conoco gas station, the Twilight Theater, and the three downtown banks were some of the town's most important businesses that catered to people in their advanced years (Figure 7). In less than five minutes, the tornado removed all of them from the landscape. Over the 
subsequent three years the community struggled to provide even the most basic services and retail options.

Two forces pulled the community in different directions. A small group of residents (led by the former mayor) wanted to see Greensburg rebuild as quickly as possible and have their lives promptly return to normalcy. On the other hand, leaders of the community focused on building "green” and encouraged business owners to meet LEED certification. ${ }^{6}$ This position did not consider how certification would impact the rebuilding of the town's commercial activities. As a result, the slow recovery of Greensburg's business district forced residents to travel at least 30 miles for even the most basic goods and services. For the younger and middle-aged residents this proved to be a noticeable inconvenience, but for the older residents it was a major source of stress and frustration because it seriously questioned their independence and ability to care for themselves. In many cases the older residents had to rely upon others to help them make necessary purchases.

One of the biggest sources of frustration among retirees was the lack of a grocery store and pharmacy. Within weeks after the tornado, the Kroger Corporation built a convenience store to supply gasoline and selected merchandise not only to local residents, but also to construction workers hired to rebuild the town. The main problem is that the store did not carry merchandise geared toward retirees. By February 2009, Kroger added a halfsize Dillons grocery store to the convenience store but it lacked space for a pharmacy. As of July 2010 Greensburg still did not have a drug store. ${ }^{7}$ This commercial shortcoming is proving to be a major hardship for the town's older folks who still have to drive 32 miles to Pratt to get their prescriptions filled. 
A second service vital to the elderly's quality-of-life is health care. Immediately after the tornado, trailers and tents served as a temporary hospital for the town. This enabled all residents, regardless of age, to receive medical attention as needed. Because city officials pressured everyone to adhere to "green" building techniques, the construction of the new Kiowa County Memorial Hospital with its fifteen acute-care beds took over 21/2 years to complete. This was particularly troubling for the older population because the lack of emergency or major medical services forced them to travel to a neighboring community. When Kiowa County's environmentally friendly, state-of-the-art hospital finally opened in March 2010, the life of Greensburg’s older population became more secure enabling them to reestablish their bonds to the community.

As time passed, other businesses that cater to the large retirement-aged population began to return to Greensburg. The reopening of the Kansan Restaurant in August of 2009 delighted the town's older residents. Prior to its opening there was no place to purchase a hot, ready-to-eat meal. But even more important to the town's older folks was the tradition of going out to eat on Sunday after church. Once the restaurant reopened, the Sunday tradition could resume. As numerous residents remarked, when the restaurant returned the town felt like home again because it enabled them to reestablish their routine and connections to the community.

A short time after the 2007 tornado, Morene Jenkins and her husband packed up what remained of their possessions and moved to Pratt to live out the rest of their retirement years. They had no intent of ever returning to Greensburg. The couple believed it would take at least ten years to recover from such a devastating event. From their perspective the storm 
completely destroyed the town's quality-of-life. For nearly three years Greensburg's downtown offered little more than basic skeleton businesses and few services. In 2010 at the third anniversary celebration, the Jenkinses saw firsthand the transformation that Greensburg has made. The grand opening of a small strip mall marked noticeable progress in town. Other downtown businesses include a grocery store, two gas stations, three banks, and a coffee shop. To the delight of many older residents, some of the old businesses are finally returning including Fleeners Furniture and The Wilde Flower Shop. By some miracle, Greensburg had risen from the prairie floor. Morene and her husband saw Greensburg in a new light. The town has ample businesses and services to provide them once again with an acceptable quality-of-life. Without much discussion they decided the time had come to return "home” (Jenkins 2010).

\section{Conclusions}

In many regards Greensburg, Kansas is a typical small, rural, American town. For decades its total population has been decreasing and the average age of its citizens has been steadily increasing. On the night of May 4, 2007 life changed dramatically for the residents of Greensburg. In the weeks and months subsequent to the storm, city officials realized the unusual opportunity it gave them. The destructive winds provided Greensburg with a clean slate upon which the community could rebuild. Because town leaders encouraged everyone to use "green" building techniques, Greensburg found itself on the map of world notoriety. Yet, rebuilding "green" has been complicated, stressful, and slow. Countless other communities have been destroyed by natural disasters, but they have recovered much 
quicker. As the work by local author Janice Haney (2009) illustrates, the process of recovering after the tornado has been fraught with difficulties and filled with raw emotions. Largely overlooked were the needs of the town's sizeable retired-aged population. A number of these oversights or mishaps have led to minor discord within the community. These sources of contention became condensation points around which we could focus our attention and learn what elements within the community are most important to older folks and are key to their strong emotional connection to place. At first glance our results may appear intuitive, but preexisting assumptions are largely a priori. There is a noticeable absence of research that examines what elements within a community help retirees develop a strong attachment to place and provide a good quality-of-life.

We assert that there are lessons to learn from Greensburg not because it is the only community to rebuild after a natural disaster, but rather because the town provides a window to understanding what communities are facing as their populations become increasingly older. Beginning in 2011 and continuing for the next two decades, approximately three million baby boomers each year will enter the retirement phase of their life. According to a study conducted by Del Webb (2010), 50 percent of baby boomers plan to relocate to another state when they retire. If previous patterns continue, many of the boomers will seek out places in the Sunbelt states that cater to their age-specific needs. As they have done throughout their lifetime, these annual waves of retiring boomers will place new and heavy demands upon the communities in which they live. Places that are cognizant of their needs and desires will be well positioned to tap into the large revenue stream ${ }^{8}$ the aging baby boomers offer. For many municipal governments, especially in the Sunbelt states, there is a 
growing sense of urgency to start preparing for the future by building communities that are friendly to retirees. The results of our research adds to our understanding of what the large baby boom population may demand.

A second lesson learned ties into the growing body of literature on understanding what is needed to help older people successfully “age in place.” Survey results from 225 older individuals indicate that the greatest source of anxiety retirees have is their ongoing struggle to maintain their independence and ensure an acceptable quality-of-life (Austin el al. 2001). Most of the existing research focuses on improving age-specific infrastructure including the aesthetics and utility of pedestrian zones, reliable and user-friendly public transportation, ensuring the availability and quality of health care and support services (Beirer 1997; Austin et al. 2001; Alley et al. 2007). As Lucinda Beirer (1997) asserts however, there are many things that communities must address if seniors are to age with independence and dignity. Yet, to better serve the needs of older folks, we need to fully understand what is important to them (Lawton 1980). Our study among retirees in Greensburg advances the research in a slightly new direction by examining what helps older folks feel comfortable, content, and emotionally connected to the community in which they live. As Setha Low and Irwin Altman (1992) contend, for people in their advanced years, places that hold deep emotional connection not only enhance self-confidence and selfperception, but also contribute to a positive quality-of-life.

From our research among older folks in Greensburg, we found that in order for retired-aged people to feel comfortable, secure, and connected to their community they must be surrounded by identifiable and familiar landmarks. These landmarks can be established 
community icons or they can be relatively new (e.g. distinctive houses with modern architecture and hand-painted signs). The longer a person lives in a place, the notable landmarks act as mnemonic devices reinforcing one's personal identity. Furthermore, these points of reference aid older folks as they navigate through their activity space within the community. As developers build modern residential subdivisions with homeowners' associations that enforce conformity in housescapes and discourage personalized identifiers, retired-aged people may not find the space user-friendly. Landmarks help retirees make a strong connection to the community in which they live.

The personal connections that people make over the course of their lifetime are key to understanding place attachment (Low and Altman 1992; Gallup and Knight 2010). Our research reveals that a space to socialize is vital if older folks are to feel content. To have a dedicated place where retirees can spend time with like-minded people enables them to reinforce and maintain ties to the community. It became evident to us that without a place to socialize, retirees can feel isolated, discontent, and the quality of their life wanes.

Finally, one of the biggest concerns older folks have is their ability to maintain their independence and self worth. Being able to meet one’s own needs goes a long way in assuaging those anxieties. As Chamlee-Wright and Storr (2009) report, basic businesses and services are key to the health and vitality of a community. For retirees, age-specific businesses are the key to securing an acceptable quality-of-life. We found that when a community is unable to provide these basic services and retail outlets, older people commonly feel discontent and their connections to the place can deteriorate because they are forced to travel elsewhere to meet those needs. 


\section{NOTES}

${ }^{1}$ One of the newest challenges U.S. society will face as the baby boom population ages is the appropriate lexicon for people in their retirement years. Most retirees dislike the terms "senior," "senior citizen,” and “elderly.” In the Spanish language there are four age groupings: jovenes (the young), mediana edad (middle age), tercera edad (third age), and mayores/viejos (the old). The English language lacks comparable politically correct terms.

${ }^{2}$ According to the 2000 census, 12.4 percent of the total U.S. population was 65 years of age or older.

${ }^{3}$ The literature provides two examples that discuss how peoples' attachment to place changes when their surroundings have been leveled. Richard Francaviglia (1978) examined Xenia, Ohio after a tornado destroyed much of the community in 1974. City planners sought to change the town's structure and eliminate the ill effects of downtown decay and increasing suburbanization. The townspeople vehemently objected because their community would become unrecognizable and their bonds to the place would be destroyed. Francaviglia explains that the rebuilt Xenia closely resembled its pre-disaster design. In a second study, Peirce Lewis (1979) describes how urban planners remade Detroit’s rundown, crime-infested city by replacing neighborhoods with crisscrossing interstate highways. When the character of the city changed, many native Detroiters lost their emotional attachment to the place and had little reason to stay.

${ }^{4}$ In 1887, the Kingman, Pratt, and Western Railroad selected Greensburg as a water refueling station along its steam engine rail line. Town officials dedicated the completed hand-dug well (32 feet in diameter and 109 feet deep) in 1888.

\footnotetext{
${ }^{5}$ The most common response to this razed landscape has been to count streets and vacant lots. Three years after the event, many residents of Greensburg were still navigating through town and giving directions by counting the number of streets from Main Street or other major arteries. Adding insult to injury were the 298 Federal
} 
Emergency Management Agency (FEMA) trailers set up to provide temporary shelter for displaced residents. Because they all looked alike, our contacts said that people in their advanced years had tremendous difficulty finding the specific trailer that was now their "home."

${ }^{6}$ LEED (Leadership in Energy and Environmental Design) is a certification system developed by the U.S. Green Building Council to assess and verify that buildings are designed, built, operated, and maintained using environmentally friendly techniques. Based on a maxiumum of 80 points, the LEED classification system ranges from "Certified” (40-49 points) through "Silver” (50-59 points) and “Gold” (60-79 points) to Platinum (80 points). In December 2007 the Greensburg City Council passed a resolution requiring 100 percent of city buildings to meet the LEED Platinum rating. According to local sources, nearly 50 percent of residential construction has followed "green” building techniques.

${ }^{7}$ Local officials are trying to persuade the town's hospital to serve as a regional pharmacy, but finding a pharmacist willing to accept the relatively low salary and lack of amenities is proving to be difficult.

${ }^{8}$ Arizona and Florida see an annual economic boom of approximately $\$ 1$ billion and \$4 billion respectively as snowbird retirees migrate south to enjoy winter in a snow- and ice-free environment (Happel and Hogan 2002; Smith and House 2006).

\section{REFERENCES:}

Adamchak, D. J., L. E. Bloomquist, K. Bausman, and R. Qureshi. 1999. Consequences of Population Change for Retail/Wholesale Sector Employment in the Non-metropolitan Great Plains: 1950-1996. Rural Sociology 64 (1): 92-112. 
Alley, D., P. Liebig, J. Pynoos, T. Banerjee, and H. Choi. 2007. Creating Elder-Friendly Communities: Preparations for an Aging Society. Journal of Gerontological Social Work 49 (1): 1-18.

Altman, I. and S. M. Low. 1992. Place Attachment. New York: Plenum Press.

Austin, C., D. Flux, L. Ghali, D. Hartley, D. Holinda, R. McClelland, J. Sieppert, and T. Wild. 2001. A Place to Call Home: Final Report of the Elder Friendly Communities Project. [http://www.gov.calgary.ab.ca/ community/publications/].

Beirer, L. M. 1997. Coming of Age in Rural Illiniois: Developing Elder-Friendly Communities, 18 April . [http://www.asru.ilstu.edu/reports/RRFfinrpt.pdf].

Blake, K. S. and D. D. Arreola. 1996. Residential Subdivision Identity in Metropolitan Phoenix. Landscape Journal. 15 (1): 23-35.

Brown, G. and C. Raymond. 2007. The Relationship Between Place Attachment and Landscape Values: Toward Mapping Place Attachment. Applied Geography 27(2): 89-111.

Burley, D., P. Jenkins, S. Laska, and T. Davis. 2007. Place Attachment and Environmental Change in Coastal Louisiana. Organization and Environment 20 (3): 347-366. 
Case, Mike. 2009. Interview by Matthew R. Cartlidge. Greensburg, Kan., 3 May.

Chamlee-Wright, E. and V. H. Storr. 2009. “There’s No Place Like New Orleans”: Sense of Place and Community Recovery in the Ninth Ward After Hurricane Katrina. Journal of Urban Affairs 31 (5): 615-634.

Chow, K. and M. Healey. 2008. Place Attachment and Place Identity: First-Year Undergraduates Making the Transition From Home to University. Journal of Environmental Psychology 28 (4): 362-372.

Colten, C. E., R. W. Kates, and S. B. Laska. 2008. Three Years After Katrina: Lessons for Community Resilience. Environment: Science and Policy for Sustainable Development 50 (5): 36-47.

Dawson, Steve. 2009. Interview by Matthew R. Cartlidge. Greensburg, Kan., 7 July.

Del Webb. 2010. 2010 Del Webb Baby Boomer Survey. [http://dwboomerssurvey.com /2010_Baby_Boomer_Survey.pdf].

Derr, V. 2002. Children's Sense of Place in Northern New Mexico. Journal of Environmental Psychology 22 (1-2): 125-137. 
EM-DAT. 2011. The International Disaster Database: Centre for Research on the Epidemiology of Disasters - CRED. [http://www.emdat.be/disaster-list]

Fankhouser, W. 2009. Interview by Matthew R. Cartlidge. Greensburg, Kan., 7 July.

Francaviglia, R. V. 1978. Xenia Rebuilds: Effects of Pre-Disaster Conditioning on PostDisaster Redevelopment. Journal of the American Institute of Planners 44 (1): 13-24.

Fried, M. 1963. Grieving for a Lost Home. In Urban Condition, edited by Leonard J. Duhl, 151-171. New York: Basic Books, Inc.

Gallup and Knight. 2010. Knight Soul of the Community: Why People Love Where They Live and Why it Matters: A National Perspective. [http://www.soulofthecommunity.org]

Gilleard, C., M. Hyde, and P. Higgs. 2007. The Impact of Age, Place, Aging in Place, and Attachment to Place on the Well-Being of the Over 50s in England. Research on Aging 29 (6): 590-605. 
Giuliani, M. V. 2003. Theory of Attachment and Place Attachment. In Psychological Theories for Environmental Issues, edited by Mirilia Bonnes, Terence Lee, and Marino Bonaiutom, 137-170. Burlington, Vt.: Ashgate Publishing Company.

Haney, J. 2009. Greensburg: The Twisted Tales, Volume II. Greensburg, Kan.: Self Publication.

Happel, S. K. and T. D. Hogan. 2002. Counting Snowbirds: The Importance of and the Problems With Estimating Seasonal Populations. Population Research and Policy Review 21 (3): 227-240.

Hay, R. 1998. Sense of Place in Developmental Context. Journal of Environmental Psychology 18 (1): 5-29.

Hayden, D. 1997. Urban Landscape History: The Sense of Place and the Politics of Space. In Understanding Ordinary Landscapes, edited by Paul Groth and Todd W. Bressi, 111133. New Haven: Yale University Press.

Hayse, A., M. Nash, B. Johnson, and S. Rice. 1979. History of Greensburg. In A History of Kiowa County, 1880-1980: A Kronicle of Kiowa County, edited by Kin Kith and Kind Friends, 32-47. Lubbock, Tex.: Taylor Publishing Co. 
Jenkins, M. 2010. Interview by Matthew R. Cartlidge. Greensburg, Kan., 1 May.

Keller, Janice. 2009. Interview by Matthew R. Cartlidge. Greensburg, Kan., 24 July.

Lawton, M. P. 1980. Environment and Aging. Monterey, Calif: Brooks/Cole Publishing Company.

Lewis, P. 1979. Defining a Sense of Place. The Southern Quarterly 17 (1): 24-46.

Low, S. M. and I. Altman. 1992. Place Attachment A Conceptual Inquiry. In Place Attachment, edited by Irwin Altman and Setha M. Low, 1-12. New York: Plenum Press.

Lynch, K. 1960. The Image of the City. Cambridge: The MIT Press.

Manzo, L. C. 2005. For Better or Worse: Exploring Multiple Dimensions of Place Meaning. Journal of Environmental Psychology 25 (1): 67-86.

Marsh, B. 1987. Continuity and Decline in the Anthracite Towns of Pennsylvania. Annals of the Association of American Geographers 77 (3): 337-352. 
McHugh, K. E. and R. C. Mings. 1996. The Circle of Migration: Attachment to Place in Aging. Annals of the Association of American Geographers 86 (3): 530-550.

Morgan, P. 2010. Towards a Developmental Theory of Place Attachment. Journal of Environmental Psychology 30 (1): 11-22.

Nostrand, R. L. and L. E. Estaville. 2001. Homelands: A Geography of Culture and Place Across America. Baltimore: Johns Hopkins University Press.

Pretty, G. H., H. M. Chipuer, and P. Bramston. 2003. Sense of Place Amongst Adolescents and Adults in Two Rural Australian Towns: The Discriminating Features of Place Attachment, Sense of Community and Place Dependence in Relation to Place Identity. Journal of Environmental Psychology 23 (3): 273-287.

Proshansky, H. M., A. K. Fabian, and R. Kaminoff. 1983. Place Identity: Physical World Socialization of the Self. s. Journal of Environmental Psychology 3 (1): 57-83.

Relph, E. 1976. Place and Placelessness. London: Pion Limited.

Rowles, G. D. 1990. Place Attachment Among the Small Town Elderly. Journal of Rural Community Psychology 11 (1): 103-120. 
Rubinstein, R. L. and P. A. Parmelee 1992. Attachment to Place and the Representation of the Life Course by the Elderly. In Place Attachment, edited by Irwin Altman and Setha M. Low, 139-163. New York: Plenum Press.

Scannell, L. and R. Gifford. 2010. Defining Place Attachment: A Tripartite Organizing Framework. Journal of Environmental Psychology 30 (1): 1-10.

Schnell, S. M. 2003. Creating Narratives of Place and Identity in "Little Sweden, U.S.A.” Geographical Review 93(1): 1-29.

Smith, J. S., M. R. Engel, D. A. Hurt, J. E. Roth, and J. M. Stevens. 2001. La Cultura de la Acequia Madre: Cleaning a Community Irrigation Ditch. North American Geographer 3 (1): 5-28.

Smith, J. S. and B. M. White. 2004. Detached from Their Homeland: The Latter-day Saints of Chihuahua, Mexico. Journal of Cultural Geography 21 (2): 57-76.

Smith, S. K. and M. House. 2006. Snowbirds, Sunbirds, and Stayers: Seasonal Migration of Elderly Adults in Florida. The Journals of Gerontology; Series B 61 (5): 232-239.

Truman, J. 2009. Professional Counselor at Kiowa County Mental Health Center. Interview by Matthew R. Cartlidge. Greensburg, Kan., 14 August. 
Tuan, Y-F. 1974. Topophilia: A Study of Environmental Perception, Attitudes, and Values. Englewood Cliffs, N.J.: Prentice-Hall Inc. . 1976. Geopiety: A Theme in Man’s Attachment to Nature and to Place. In Geographies of the Mind: Essays in Historical Geosophy in Honor of John Kirtland Wright, ed. D. Lowenthal and M. J. Bowden, 11-39. New York: Oxford University Press. 1977. Space and Place: The Perspective of Experience. Minneapolis: University of Minnesota Press. . 1980. Rootedness Versus Sense of Place. Landscape 24 (1): 3-8.

U.S. Census. 1961. 1960 Census of Population and Housing. Washington, DC: Government Printing Office.

U.S. Census. 2001. 2000 Census of Population and Housing. Washington, DC: Government Printing Office.

West, Ruth. 2009. Interview by Matthew R. Cartlidge. Greensburg, Kan., 14 June. 
Wiles, J. L., R. E. S. Allen, A. J. Palmer, K. J. Hayman, S. Keeling, N. Kerse. 2009. Older People and Their Social Spaces: A Study of Well-Being and Attachment to Place in Aotearoa New Zealand. Social Science \& Medicine 68 (4): 664-671.

\section{FIGURE CAPTIONS:}

Fig. 1 - Map: Location of Greensburg, Kansas. (Cartography by Jeffrey Smith)

Fig. 2 - Billboard on Highway 54 one mile west of Greensburg, Kansas. (Photo by Jeffrey Smith, May 2010)

Fig. 3 - The grain elevator in Greensburg was the only structure left undamaged after the EF5 tornado. (Photo by Matthew Cartlidge, July 2009)

Fig. 4 - The star leaning against the street sign is one of many landmarks created and erected by local school children in Greenburg, Kansas. (Photo by Matthew Cartlidge, October 2008)

Fig. 5 - Example of the signs provided to all households in Greensburg, Kansas. (Photo by Jeffrey Smith, May 2010) 
Fig. 6 - "The Silo House” in Greensburg, Kansas. To demonstrate the durability of the house an automobile was dropped from a crane on top of the house. The car was severely damaged. (Photo by Matthew Cartlidge, May 2010)

Fig. 7 - Mental Map drawn by Greensburg resident Mike Case, 2009.

Table 1 Population of Greensburg, Kansas, 1900 - 2008.

$\begin{array}{lrrr}\text { Year } & \text { Population } & \text { Year } & \text { Population } \\ 1900 & 444 & 1960 & 1,988 \\ 1910 & 1,199 & 1970 & 1,907 \\ 1920 & 1,420 & 1980 & 1,885 \\ 1930 & 1,338 & 1990 & 1,792 \\ 1940 & 1,417 & 2000 & 1,574 \\ 1950 & 1,723 & 2008 & 1,280\end{array}$

Source: U.S. Census 1900 to 2000; www.city-data.com 2010. 